\title{
Maria Ochwat
}

Ph.D., Wyższa Szkoła Bankowa w Poznaniu

https://orcid.org/0000-0001-6192-423X

\section{Nina H.B. Jorgensen, The Extraordinary Chambers in the Courts of Cambodia, Edward Elgar Publishing, Cheltenham, UK, Northampton, MA, USA}

It will shortly be seventeen years since the Extraordinary Chambers in the Courts of Cambodia were created and twenty-one years since the Khmer Rouge Government was overthrown. The Pol Pot regime claimed the lives of at least two million people. Nonetheless, today many former and younger leaders belong to the ruling Cambodian People's Party. A question arises as to whether, despite the creation of the criminal tribunal, the victims and their families will ever see justice being done.

The period of the Khmer Rouge rule can undoubtedly be considered as the bloodiest period in the history of Cambodia. The Communist Party of Kampuchea, known as the Khmer Rouge, took power in Cambodia on 17.4.1975 and exercised it until January 1979. The Khmer Rouge were a radical communist movement which aimed at introducing the ideology of Marxism and Maoism in Cambodia. They were led by Pol Pot. The Khmer Rouge showed utter disregard for human life and human rights, used repressive forms of government and killed people on a massive scale. They took away the lives of two million people and forced almost the same number of those living in Phnom Penh to settle down in rural areas and take up work on farms. Thousands died during the resettlement. The Khmer Rouge were planning to turn Cambodia into a rural, classless society, without the rich, the poor, without exploitation. In order to achieve this, they eliminated money, free market and private property (possession of any property such as watches, radios, foreign currency or gold was punishable 
by death). Traditional education, religion and traditional Khmer culture were abolished, but wearing western style of dress was forbidden. Objects of cult, schools, shops, banks, government offices and other buildings were closed or transformed into prisons, re-education camps, stables and granaries. Public transportation was abolished to prevent people from contacting their families in other parts of the country. People were not allowed to travel, meet others or even hold discussions. Family relations were criticised, it was ideal to have none. The Khmer Rouge tried to create a substitute for a family in accordance with a collectivist pattern. Seeking to achieve the greatest demographic advantage over other countries, they ordered people to follow a dogmatic, revolutionary morality. Nonmarital sex was forbidden, one had to obtain permission to get married. It was maintained that only a 'pure race' was able to start a revolution and guarantee its success, thus, thousands of military officials, public officers and policemen classified as 'not pure enough' were arrested and killed. Within three subsequent years not only were all intellectuals targeted, but also representatives of the Cham, Vietnamese or Chinese minorities or even some of the party members. Plans for several years were introduced which assumed an increase in the production of rice, considered a symbol of state independence and the most obvious evidence for economic self-sufficiency.

In the 1970s, tension in relations between Vietnam and Cambodia occurred, followed by the outbreak of a war. The Pol Pot regime fell. Despite this, human rights, genocide and crimes against humanity had not been discussed until 1991, when the Paris Peace Conference appointed the United Nations Transitional Authority in Cambodia. Its role was, among others, to manage repatriation of refugees and to guarantee that human rights are respected. The intent was to prepare the nation for fair and open elections, as well as to bring about peace between the warring partisan fractions. The UN mission ended in May of 1993 and the process of building a democratic system began. This did not reduce the political tension. In 1997, a coup d'état, organised by Hun Sen who was seeking to monopolise the power, took place. Prince Norodom fled abroad. Although a coalition was rebuilt in subsequent elections in 1998, Hun Sen managed to consolidate his power. Fighting and political turmoil were not conducive to solving the problems of the country. Still, the Khmer Rouge rebellion slowly began to be contained and overcome. Pol Pot was captured and died shortly after, in 1998. The last and most significant activists surrendered to the authorities in 1996. Efforts aiming at judging the Khmer Rouge leaders began. However, the path to establishing a tribunal that could hold the Khmer Rouge leaders accountable was a long one. 
Cambodia requested assistance from the UN to set up trial proceedings for the first time in 1997 and after the conflict, in 1998, the government of Cambodia and the UN cooperated closely to create the concept of a Cambodian-international tribunal. Negotiations lasted until 2003. While the new hybrid tribunal began its activity at the beginning of 2006, only a few staff-members had been enrolled. In June 2007, the tribunal was fully functional.

The book by Nina H.B. Jorgensen entitled The Extraordinary Chamber in the Courts of Cambodia is entirely devoted to this international criminal tribunal. Yet, while the author uses the term hybrid tribunal several times, she does not explain, however, what hybrid tribunals are, while this is undoubtedly important for the functioning and evaluation of the work of the Extraordinary Chambers in the Courts of Cambodia.

International criminal tribunals grew from the need to realise the idea of social justice, and serve the interest of not only a given country, but also the whole international community. In addition to the need to exercise justice effectively, it should also be done in an efficient, quick, and whenever possible, inexpensive way. Furthermore, the existence of international criminal tribunals may constitute a form of encouragement for national authorities to pursue for criminal prosecution, those guilty of grave human rights violations. Should such need arise, tribunals may also substitute for national courts if they are unable or unwilling to administer justice. Today, subject literature distinguishes four types of criminal tribunals: Nuremberg-type tribunals, ad hoc tribunals, hybrid tribunals and permanent criminal tribunals.

Extraordinary Chambers in the Courts of Cambodia are an example of an international hybrid tribunal. Tribunals of this type did not appear until the beginning of the $21^{\text {st }}$ century, they were created as a consequence of the search by international community for better and better mechanisms aiming at restoring justice and settling the past in a just way. This phenomenon has been known as transitional justice. This is due to the fact that in order to achieve stability and peace in the society, it is essential that the created institutions and mechanisms do not become tools for taking revenge or for providing ways to deny the past in the name of the future. They should, on the other hand, serve the truth, give back voice and dignity to the victims, ensure that the guilty individuals are held responsible, restore the rule of law, repair the damage done to the individual and state, compensate for the caused harm, conduct institutional reform and provide a basis for sustainable development, promote reconciliation and inspire public debate. International hybrid tribunals include: the above mentioned 
Extraordinary Chambers in the Courts of Cambodia, the Special Court for Sierra Leone, the Special Tribunal for Lebanon, The Special Panels for Serious Crimes (The East Timor Tribunal), the War Crimes Chamber for Bosnia and Herzegovina, the International Judges and Prosecutors Programme in Kosovo.

It is difficult to identify a catalogue of common characteristics of hybrid tribunals that would distinguish them from other types of tribunals. This is because hybrid tribunals are not uniform. Their typical features include: mixed personnel composition - both judges, prosecutors and administrative employees are recruited from the country where the tribunal proceeds, as well as from among the representatives of the international community designated by the UN; the reason for which the tribunal is established, which is providing state support, an internal justice mechanism, especially where it is inefficient or does not function at all; transitional character - such tribunals are not created to be permanent, but only to provide ad hoc aid; covering with subject-matter jurisdiction the most serious international crimes, including genocide, crime against humanity or war crimes; functioning on the territory of a given country that is where the crimes were committed. Moreover, hybrid tribunals are dissimilar with regard to legal framework. This regulates how they function, as well as their legal construction, inner structure, financing and maintenance costs.

Therefore, given the large scale of the tragedy which Cambodia experienced, existence of a real threat of further serious human rights violations on a massive scale and, at the same time, the need to search for more effective methods to prevent similar tragedies in the future and to hold the guilty accountable, research in this area seems well-founded. The book by Nina H.B. Jorgensen is one of very few scientific publications on the Extraordinary Chambers in the Courts of Cambodia. It is worth emphasising that the Author had the opportunity to become familiar with the functioning of the tribunal from within, being, as she put it 'the first employee of the United Nations Assistance to the Khmer Rouge Trials in the Pre-Trial Chamber and then to serve as an adviser to the ECCC Supreme Court Chamber.' Therefore, bearing the above in mind, the author could have conducted interviews with the employees of the tribunal, and, most importantly, could have done research among the citizens of Cambodia to establish how they assess the work of the tribunal and whether, in their opinion, reconciliation is at all possible. Such interviews and surveys would have not only complemented the publication, but could also have provided information on how to improve the functioning of this tribunal or other international tribunals in the future. Meanwhile, the author bases 
her work mostly on compilations by other authors, Internet sites, papers related to the documents regulating the functioning of the tribunal and selected fragments of the case files. Two of the above mentioned sources are available on the website of the tribunal.

The reviewed book consists of an introduction and twelve chapters with the following titles: Introduction, Legality, Structure, Procedure, Cases, Proceedings, Crimes, Liability, Sentencing, Victims, Legitimacy and Legacy. However, the book lacks a summary of the findings. Such a division and the order in which the content is presented do not seem to be fully justified. In my opinion, it would seem more reasonable to present the history of genocide and crimes against humanity in Cambodia at the beginning of the book, then to depict the Khmer Rouge, their ideology and activities. This part should be followed by the history of the tribunal, the legal basis of its functioning, principles of operation, structure and organisation, as well as discussion of the criminal proceedings, whereas the presentation of the defendants' cases, analysis of their criminal trials and, finally, assessment of the court's work should be provided at a later stage.

Finally, it seems necessary to embed the Extraordinary Chambers in the Courts of Cambodia in a slightly broader context than the Author has done. It would be necessary to define the place the Extraordinary Chambers in the Courts of Cambodia occupy in the international criminal justice system. It would also be reasonable to depict Cambodian society before the time of the Khmer Rouge, during their rule and, finally, at present. In contrast, the author confined her discussion to citing the most important historical events, but she did not explain their impact on the society. I am convinced that such an explanation could be helpful to the readers, allowing them to better understand why the appointment of the Extraordinary Chambers in the Courts of Cambodia was such a long, complex and difficult process. It could also enable the readers to see why a significant part of the society is not interested in the tribunal's activities, which problems modern Cambodia is facing today and what attitude politicians have towards the Extraordinary Chambers in the Courts of Cambodia.

Despite the fact that the constitution of Cambodia underlines the importance of political pluralism, in reality there is one dominant party, that is - the Cambodian People's Party. Since 1985, Hun Sen has uninterruptedly served as the Prime Minister. Experts claim, however, that in spite of declaring its commitment to democratic values, Cambodia clearly has reverted to communist traditions and authoritarian rule. Hun Sen has also been accused of violating human rights, as well as suppressing the political opposition, and is often described as a dictator. The politics 
of Hun Sen became stricter after the parliamentary elections in 2013. In order to guarantee victory in subsequent parliamentary elections in 2018, and earlier in local elections - in June of 2017, Hun Sen decided to weaken political opposition, among others, by introducing censorship, arrests in the guise of representing a threat to 'public order, image and national security.' Finally, on 16.11.2017, controlled by the High Court, he decided to dissolve the opposition party, while at the same time, banning its one hundred and eighteen members from political activity for a period of five years. Hence, media, political opposition and nongovernmental organisations that Hun Sen perceived as threatening with regard to the coming parliamentary elections, became targeted.

While undoubtedly positive economic changes have taken place in Cambodia over the recent years, much remains to be done. The greatest challenges which the state is facing include: prevalent corruption, growing inequalities (among others, in term of income, between people living in rural and urban areas, unjustified differentiation on the basis of sex), more difficult access to education for girls and women, low paid positions in public institutions, violence towards women and girls, the fight against illiteracy, poverty, human trafficking, sexual exploitation, as well as trade in human organs. Human rights are systematically violated, especially the right to a fair trial, freedom of speech, freedom of assembly and association, the rights of political asylum seekers. Cases of arbitrary detention and retention, as well as of 'disappearance' have also been reported. The attacked groups mostly include: human rights defenders, political opponents, activists and intellectuals. Racial hatred is mostly directed at the Vietnamese minority.

Despite the fact that Cambodia has ratified several UN human rights documents, the awareness of their content and the level of compliance are very low. Furthermore, attempts at creating a regional system of human rights protection were unsuccessful, and protection as offered under ASEAN is ineffective. Psychological, legal and humanitarian assistance is offered by non-governmental organisations because no national mechanisms of human rights protection, such as ombudsman or human rights commissions exist in Cambodia. Cambodians must seek justice exclusively in the court of law, but the costs, lack of legal awareness and lengthy criminal proceedings which are usually terminated, discourage exercising any rights. It should also be noted that citizens have negligible impact on their representatives' activities, and thus fewer chances to protect their rights and freedoms. The existing Constitution, for example, does not guarantee any form of direct democracy, such as a referendum. Indeed, 
citizens are not entitled to the right of initiative, and they cannot lodge a complaint with regard to activities of state institutions. The situation in Cambodia is, thus, becoming increasingly tense.

A discussion devoted to the current social situation in Cambodia is important as it would allow the reader to understand the attitude to the Extraordinary Chambers in the Courts of Cambodia of the politicians belonging to the governing party, and their rather prevalent hostile propaganda and the way the society perceives the tribunal would become evident. This would also provide an opportunity to answer the question of whether the activity of the tribunal is seen as a success or a failure.

Beyond the aforementioned, the author did not present the aim of the study, hypothesis and the methodology in the introduction. While the aim of each particular chapter is provided at the beginning of each chapter, nonetheless, not every purpose has been fulfilled. What is more, the Author mostly uses the historical method and the technique of document analysis. She also demonstrates the institutional, functional, system and the normative approaches. Although the description of the structure and organisation of the tribunal, the criminal procedure and presentation of the legal foundations of the functioning of the tribunal, case studies and the victims is a comprehensive and outstanding, it leaves the reader with the impression that the Author focuses on the description of the tribunal, but does not analyse and evaluate its functioning and activities. Finally, specific recommendations on how to improve the work of the tribunal are missing. Indeed, in the work, the Author does not exactly refer to the criticism of the tribunal by some of the politicians and citizens, as well as the specific crises around the activities and functioning of the Extraordinary Chambers in the Courts of Cambodia - and they are, as commonly known, numerous. It is suffice to mention that the credibility of the tribunal has also been dented by the accusations of corruption and the conflict concerning the interpretation of the procedural law and assessment of evidence, which resulted in the resignation of the judges.

Considerable hopes have been placed on the Extraordinary Chambers in the Courts of Cambodia since the very beginning. Although the results of the research commissioned by the tribunal show that the society is satisfied with its establishment, the discussion on the role and functioning of the Extraordinary Chambers in the Courts of Cambodia is not devoid of criticism. This mainly concerns subject-matter jurisdiction (only nine people responsible for genocide and crimes against humanity had been accused). According to experts, too much time had passed since the end of the Khmer Rouge rule when the tribunal was created, and the trials are 
unnecessarily prolonged. What is more, the tribunal consumes enormous sums of money 'not commensurate with the results'.

It should also be noted that the question about the future of the tribunal after the last parliamentary elections in 2018 remains open. Further human rights restrictions introduced by Hun Sen may soon totally paralyse the functioning of the tribunal and thus lead to its premature dissolution.

The final part of the work should include evaluation of the functioning and activity of the Extraordinary Chambers in the Courts of Cambodia. The Author refrains from answering the question of whether the activity of the tribunal could be perceived in terms of success or failure. This is undoubtedly not an easy task, however, an attempt at such evaluation would be appropriate in this work. Although the Author mentions the possibility of extending the period of functioning of the tribunal, she does not provide any possible scenarios. The point entitled 'Cambodia Tomorrow' does not offer an answer to the question of how the social, political and economic situation in this country could develop and what the prospects of the tribunal could be.

Overall, however, the publication, regardless of my comments, is undoubtedly valuable and one worth recommending. 